\title{
Relathionsip Between Money Velocity And Inflation To Increasing Stock Investment Return: Effective Strategic By Jakarta Automated Trading System Next Generation (JATS-NG) Platform
}

\author{
Rico Nur Ilham ${ }^{1 *}$, Arliansyah ${ }^{2}$, Reza Juanda ${ }^{3}$, Muhammad Multazam ${ }^{4}$, Andri Saifanur ${ }^{5}$ \\ ${ }^{1,2,3,4,5}$ Faculty of Economic and Business, Universitas Malikussaleh \\ Corresponding Author: riconurilham@unimal.ac.id
}

\begin{abstract}
This study aims to formulate strategies to avoid macroeconomic risks in investing in the Indonesian capital market so that more people will be able to trade in financial instruments traded in the Indonesian capital market using an integrated online transaction system. This type of research is quantitative descriptive with the research population of 20 State-Owned Enterprises (BUMN) listed on the Indonesia Stock Exchange. The type of data in this study is time series data taken from 2016 to 2020 by conducting a documentation study conducted on the publication of annual financial statements (Financial Statements), so that the target population is 40 (8 Companies x 5 Years) annual financial report data for the research sample. The data analysis method in this study uses Moderate Regression Analysis (MRA) and data analysis uses the Smart PLS statistical software. The outputs of this research are publications of reputable international journals, international proceedings and reference books for ISBN certified research results with TKT level 3.
\end{abstract}

Keywords : Velocity Of Money, Inflation, return, JATS-NG

\section{BACKGROUND}

In the concept of investing in the capital market and money market sectors, investors still provide high attractiveness with standardized transaction mechanisms in various stock exchanges around the world. The capital market is a business entity that brings together parties who need long-term funds with capital owners. The party that needs capital is the company or issuer. While the owners of capital are investors (or the public). Shares and bonds, apart from being bought, can also be sold.

The specific purpose of this study is to formulate a strategy to minimize the impact of velocity of money and other macroeconomic factors that can affect the rate of return on investment in the capital market, namely inflation, Rupiah/US Dollar exchange rate and currency turnover which are significantly negative on stock returns. It can be explained that when the Rupiah exchange rate against the US Dollar weakens, it will have a negative effect on the capital market because the capital market becomes unattractive because investors tend to prefer to save money in Dollars.(Yuswandy Yoedy, 2013).

The research stage will be accompanied by the implementation of public discussion activities and special training to understand the application of the Jakarta Automated Trading System Next Generation (JATS-NG) application. The Focus Group Discussion will be attended by stakeholders from institutions related to the Indonesia Stock Exchange, Securities Companies, and Investors. Meanwhile, analysis training related to integrated online trading transactions will invite financial technology analysts. 
The Influence of Work Ethics, Work Involvement and Personality on Employee Performance virzaerika@gmail.com

Departing from the problems and theories above, the urgency of this research is expected to help research the effect of velocity of money and inflation on investment returns in the Indonesian capital market with an integrated online transaction system through the Jakarta Automated Trading System Next Generation (JATS- NG) can foster investment interest in the Indonesian capital market and so that investors can carry out investment risk management properly in order to generate maximum profits.

\section{RESEARCH QUESTIONS AND HYPOTHESES}

1. Does the Inflation Rate affect the return on stock investments?

Inflation is an event that describes the situation and conditions where the price of goods has increased and the value of the currency has weakened (Lubis, 2012). Inflation is defined as a tendency to increase the price of products as a whole so that there is a decrease in the purchasing power of money (Tandelilin, 2010). Based on the opinion of experts, it can be concluded that inflation is a process of increasing prices continuously which causes a decrease in the value of the currency and people's purchasing power. In line with Muhammad's research (2016), it is found that inflation has a significant negative effect on stock returns in banking companies.

Hypothesis 1:

Inflation rate has a negative and significant effect on Cryptocurrency returns.

The formulation of the inflation rate variable hypothesis in this study refers to several studies, including (Sathyanarayana \& Gargesa, 2018), Suriyani \& Sudiartha (2018), Kurniasari et all (2018).

2. Does the Velocity of Money affect the return on stock investments?

Liu \& Tsyvinski (2018) conducted a study on electronic banking in Finland and its effect on velocity of money. The purpose of this study is to see the impact on the velocity of advances in banking technology that occurred in Finland. What economists call the quantity theory of money, velocity is a significant movement/driver of token prices.

Hypothesis 2:

Velocity of Money has a positive and significant effect on stock investment returns.

The formulation of the hypothesis of the Velocity of Money variable in this study refers to several studies, including RG Anderson et all (2015) Money and Velocity During Financial Crises: From the Great Depression to the Great Recession. Research conducted by Sharma \& Syarifuddin (2019) Determinants of Indonesia's Income Velocity Of Money and research from (Prasetyo, 2018) Determinants Of Demand For Money And The Velocity Of Money In Indonesia.

3. Can the Jakarta Automated Trading System Next Generation (JATS-NG) application moderate the effect of the Inflation Rate and Velocity of Money on stock investment returns?

In evaluating assets, investors always show aspects of the estimated rate of return produced by the asset, or the level of added value of the investment embedded in the asset at a later time. The return on deposits traded in the foreign exchange market is determined by the interest rate and the expected changes in exchange rates.

Hypothesis 3:

The Jakarta Automated Trading System Next Generation (JATS-NG) application moderates the effect of Inflation and Velocity of Money on stock investment returns. (2015), Sharma \& Syarifuddin (2019) and Prasetyo (2018).

\section{LITERATURE REVIEW 3.1 Theory Markowitz. Portfolio}


The company's risk is more related to changes in the micro condition of the securities issuing company. Portfolio management states that a company's risk can be minimized by diversifying assets in a portfolio, as Harry Makowitz introduced in 1952 on the theory related to investor estimation of risk and return expectations by combining assets into an efficient portfolio diversification.

\subsection{Theory Classic Money Request}

According to the classical economic view, the function of money is only as a medium of exchange. Therefore, the quantity of money demanded is proportional to the level of output or income. If the level of output increases, the quantity of money demanded will increase. Irving Fisher explained the theory of the value of money called Transaction Velocity Theory, complementing David Ricahrdo's theory which did not pay attention to the velocity factor of money circulation. Fisher argued that the speed of money supply and the velocity of circulation of goods and services were very important factors in measuring the value of money.

\subsection{Concept Payment and Transaction System}

The payment system implemented is a form of Bank Indonesia's task to maintain rupiah stability as mandated in Law no. 23 of 1999 concerning Bank Indonesia. In general, the payment system has a goal, namely to encourage the national economy and to increase economic activity through a more conducive business environment and to increase foreign power and the image of the national economy so as to encourage foreign investors to enter Indonesia.

\subsection{Theory Return Investment}

according to (Dimson, Marsh, \& Staunton, 2015), return is yield and capital gain(loss)". Yield is cash flow that is paid periodically to investment holders. While capital gain (loss) is the difference between the price of an investment at the time of purchase and the price at the time of sale.

\section{RESEARCH RESULTS AND DISCUSSION}

\subsection{Descriptive Statistics}

Descriptive statistics provide a general description of the research object that is sampled, the explanation of the data through descriptive statistics is expected to provide an initial picture of the problem being studied. Descriptive statistics are focused on the maximum, minimum, average (mean) and standard deviation values. The complete descriptive statistics are in table 4.1:

Table 4.1 Descriptive Statistics

\begin{tabular}{|l|c|c|c|}
\hline & $\begin{array}{c}\text { IMBAL HASIL INVESTASI } \\
(\mathrm{Y})\end{array}$ & $\begin{array}{c}\text { VELOCITY OF MONEY } \\
(\mathrm{X} 1)\end{array}$ & $\begin{array}{c}\text { INFLASI } \\
(\mathrm{X} 2)\end{array}$ \\
\hline Mean & 2760.300 & 0.707842 & 2.888000 \\
\hline Median & 2562.000 & 0.192489 & 3.020000 \\
\hline Maximum & 7033.000 & 2.555820 & 3.610000 \\
\hline Minimum & 313.0000 & 0.052338 & 1.680000 \\
\hline Std. Dev. & 1555.041 & 0.959751 & 0.651480 \\
\hline Skewness & 0.903465 & 1.330376 & -1.028202 \\
\hline Kurtosis & 3.572006 & 2.990184 & 2.808955 \\
\hline Jarque-Bera & 5.986974 & 11.79950 & 7.108832 \\
\hline Probability & 0.050112 & 0.002740 & 0.028598 \\
\hline Sum & 110412.0 & 28.31368 & 115.5200 \\
\hline Sum Sq. Dev. & 94307998 & 35.92378 & 16.55264 \\
\hline Observations & 40 & 40 & 40 \\
\hline
\end{tabular}

Sumber : Hasil Penelitian, data diolah (2021)

Based on table 4.1 above, it can be seen that the number of observations made for income in this study were 40 observations. The lowest value of return on investment in this study is 313,0000 $(31.30 \%)$ and the highest score is $7033,000(703,300 \%)$. The average value of income at 2760,300 
The Influence of Work Ethics, Work Involvement and Personality on Employee Performance virzaerika@gmail.com

(276.030\%)with the standard deviation value1555,041(155,504.1\%). The standard deviation value is smaller than the average value. This indicates a low fluctuation in investment returns in the sample in this study.

Furthermore, the observations made for velocity of money in this study were 40 observations. Lowest valuevelocity of money in this study are 0.052338 (5.2338\%) dthe highest value is 2.555820 $(255.582 \%)$. The average value of income at $0.707842(70.7842 \%)$ with the standard deviation value 0.959751 (95.9751). The standard deviation value is greater than the average value. It shows fluctuationvelocity of money high in the sample in this study.

The observations made for inflation in this study were 40 observations. The lowest value of inflation in this study is $1.680000(168 \%)$ and the highest score is $3.610000(361 \%)$. The average value of inflation market capitalization is 2.888000 (288.8\%) with a standard deviation value $0.651480(65.148 \%)$. The standard deviation value is smaller than the average value. This shows that a small inflation rate in the sample will affect this research.

\subsection{Classical Assumption Test \\ 4.2.1 Normality Test}

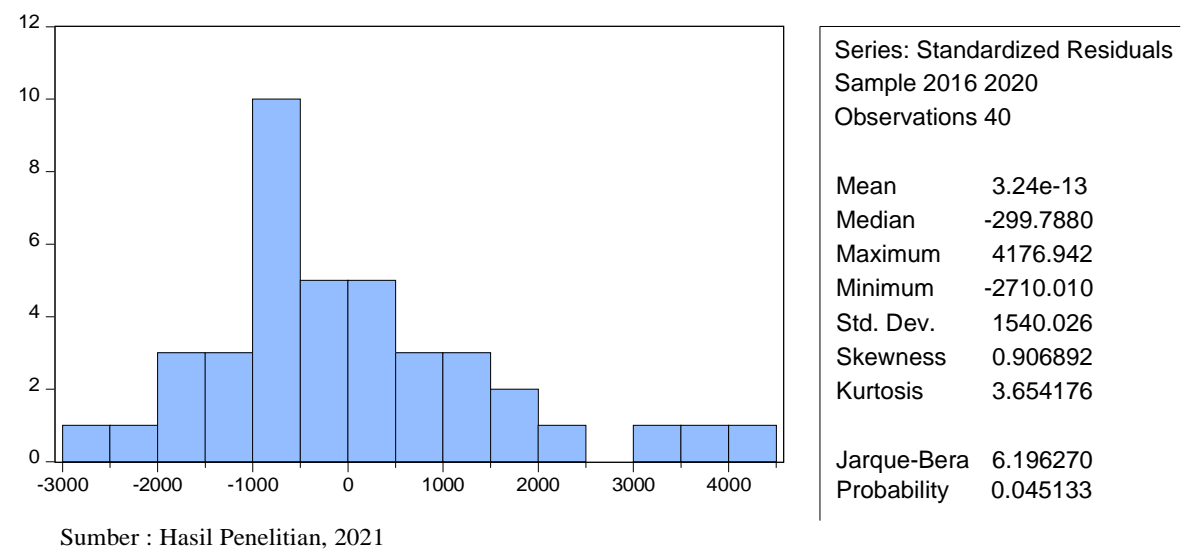

Figure 4.1 Histogram Normality Test

Based on Figure 4.1. Based on the picture above, it can be seen that the probability value in the Jarque-Bera test is 0.045133 where this value is below the standard error tolerance value (5\%). Therefore, it can be concluded that in this study it is not normally distributed.

\subsubsection{Heteroscedasticity Test}

Table 4.2 Heteroscedasticity Test (Glajser)

\begin{tabular}{|c|rrrr|}
\hline Variable & Coefficient & Std. Error & t-Statistic & Prob. \\
\hline C & 891.9389 & 782.7968 & 1.139426 & 0.2618 \\
\hline VELOCITY_OF_MONEY_X1_ & 84.84552 & 174.0919 & 0.487361 & 0.6289 \\
\hline INFLASI_X2_ & 67.07014 & 256.4696 & 0.261513 & 0.7951 \\
\hline
\end{tabular}

Sumber: Hasil Penelitian, 2021

Based on the table above, it can be seen that all independent variables in the Glajser test have probability values above 0.05 , therefore it can be concluded that there is no symptom of heteroscedasticity in this study. 


\subsubsection{Multicollinearity Test}

Table 4.3 Multicollinearity Test

\begin{tabular}{|c|c|c|c|}
\hline & $\begin{array}{c}\text { IMBAL_HASIL_INVESTASI } \\
\text { Y_ }\end{array}$ & $\begin{array}{c}\text { VELOCITY_OF_MONEY } \\
\text { X1_ }\end{array}$ & INF \\
\hline $\begin{array}{c}\text { IMBAL_HASIL_INVESTASI } \\
\text { Y_ }_{-}\end{array}$ & 1 & & \\
\hline $\begin{array}{c}\text { VELOCITY_OF_MONEY X } \\
1_{-} \\
\text {INFLASI X }\end{array}$ & & & \\
\hline
\end{tabular}

Based on the table above, it shows that this model is not multicollinear by looking at the output between the independent variables in the regression where the output is less than 0.8 .

\subsubsection{Autocorrelation Test}

Table 4.4. Autocorrelation Test

\begin{tabular}{|l|r|l|r|}
\hline R-squared & 0.754126 & Mean dependent var & 2760.300 \\
\hline Adjusted R-squared & 0.680364 & S.D. dependent var & 1555.041 \\
\hline S.E. of regression & 879.1633 & Akaike info criterion & 16.60814 \\
\hline Sum squared resid & 23187842 & Schwarz criterion & 17.03036 \\
\hline Log likelihood & -322.1627 & Hannan-Quinn criter. & 16.76080 \\
\hline F-statistic & 10.22377 & Durbin-Watson stat & 1.804662 \\
\hline Prob(F-statistic) & 0.000001 & \multicolumn{1}{|l}{} \\
\hline
\end{tabular}

Sumber: Hasil Penelitian, 2021

The autocorrelation test from table 4.4 above can be seen from the value of Durbin Watson in this study. The value of Durbin Watson in this study is1.804662. This value is between the tolerance values in the autocorrelation test, namely -2 and 2 . Therefore, it can be concluded that this study is free from autocorrelation symptoms, meaning that in this research model there is no interference with the correlation between the time periods used in each variable.

\subsubsection{Panel Data Estimation}

Table 4.5 Estimated Panel Data

\begin{tabular}{|l|r|r|r|r|}
\hline \multicolumn{1}{|c|}{ Variable } & Coefficient & \multicolumn{1}{c|}{ Std. Error } & \multicolumn{1}{c|}{ t-Statistic } & \multicolumn{1}{c|}{ Prob. } \\
\hline C & 1987.095 & 664.4630 & 2.990527 & 0.0055 \\
\hline VELOCITY_OF_MONEY & & & & \\
\hline \multicolumn{1}{|c|}{ INFLASI X2_ } & -87.83383 & 147.7748 & -0.594376 & 0.0567 \\
\hline R-squared & 289.2582 & 217.6996 & 1.328703 & 0.0940 \\
\hline Adjusted R-squared & 0.754126 & Mean dependent var & 2760.300 \\
\hline S.E. of regression & 0.680364 & S.D. dependent var & 1555.041 \\
\hline Sum squared resid & 879.1633 & Akaike info criterion & 16.60814 \\
\hline Log likelihood & 23187842 & Schwarz criterion & 17.03036 \\
\hline F-statistic & -322.1627 & Hannan-Quinn criter. & 16.76080 \\
\hline Prob(F-statistic) & 10.22377 & Durbin-Watson stat & 1.804662 \\
\hline Sumber : Hasil Penelitian, 2021 & 0.000001 & & \\
\hline
\end{tabular}
is as follows:

Based on the table above, the regression equation model that can be arranged in this study

$$
\begin{aligned}
& \mathrm{Y}=+\beta 1 \mathrm{X} 1+2 \mathrm{X} 2+\mathrm{e} \\
& \mathrm{Y}=1987.095+(-87.83383 \mathrm{X} 1)+289.2582 \mathrm{X} 2+\mathrm{e}
\end{aligned}
$$

\section{CONCLUSION}

\section{Simultaneous Test}

a. Influence Velocity Of Money Against Yield (H1)

Based on the test results using the Eviews 10 application, it is known that the tcount value of the asset price is -0.594376 significantly 0.0567 . The ttable value in this study calculated by $\mathrm{df}=$ $\mathrm{nk}$ is 2.02439 with a significance of 0.05 . Then it can be seenvelocity of moneynegative and significant effect on returns. This is indicated by the results of the tcount $(-0.594376) t$ table (2.02439) 
The Influence of Work Ethics, Work Involvement and Personality on Employee Performance virzaerika@gmail.com

and significant value 0.05670 .05 . So it can be concluded that the variablevelocity of money negative and significant effect on returns.

b. Effect of Inflation on Yield (H2)

Based on the test results using the Eviews 10 application, it is known that the tcount value of inflation is1.328703 significantly0.0940. The ttable value in this study calculated by $\mathrm{df}=\mathrm{nk}$ is 2.02439 with a significance of 0.05 . So it can be seen that inflation has a negative and insignificant effect on yields. This is indicated by the results of the tcount $(1.328703)<t$ table $(2.02439)$ and significant value 0.09400 .05 . So it can be concluded that the inflation variable has a negative and significant effect on returns.

\section{Partial Test}

The results showed that the variablevelocity of money and inflation simultaneously on yields. This is based on the results of Fcount of 10.22377 with significant level 0.00001 and the value of Ftable in this study calculated by $\mathrm{df}=\mathrm{nk}$ is 3.24 with a significance of 0.05 . Because the value of Fcount is equal to10.22377 < Ftable value of 3.24 and significance probability value Fcount 0.00001 $<0.05$, so it can be concluded that together the independent variables arevelocity of money and inflation has a negative and significant effect on the dependent variable, namely yield.

\section{ACKNOWLEDGMENT}

Thank's a lot to Radja Publika as the Head Officer of IJEBAS Journal who has facilitated the process of publishing this scientific article and also especially to LPPM Universitas Malikussaleh. Who is willing to cooperate in the process of publishing articles about Relathionsip Between Money Velocity And Inflation To Increasing Stock Investment Return: Effective Strategic By Jakarta Automated Trading System Next Generation (JATS-NG) Platform with Contract Number: 110/PPK-2/SPK-JL/2021 and Reference Code: 21.04.FEB.01 at 15th july 2021.

\section{REFERENCES}

Dimson, E., Marsh, P., \& Staunton, M. (2015). Chapter 11. Equity dividends. In Triumph of the Optimists (pp. 149-162). https://doi.org/10.1515/9781400829477-012 (14)

Ilham, Rico Nur. (2017). The effect of earnings management on firm value with good corporate governance. (1)

Keown, AJ, Laux, P., \& Martin, JD (2005). The Information Content of Corporate Investment Announcements: The Case of Joint Ventures. Research in Finance. https://doi.org/10.1016/S0196-3821(05)2202-6 (12)

Muammar Gaddafi et all (2018). Effect of Manufacturing Company's Financial Performance on Stock Returns on the Indonesia Stock Exchange. ournal article Accounting, Auditing \& Information Research Media.April 2008 Indonesia.

Rico Nur Ilham et.all (2019). Challenges in Effective Application of the Indonesian Capital Market. Advances in Economics, Business and Management Research, volume 100. International Conference of Organizational Innovation (ICOI 2019)

Tandelilin, E. (2010b). Fundamentals of Investment Management. Finance, 34. (17)

UURI, 1995. (1995). Capital Market Law. Law of the Republic of Indonesia Number 8 of 1995. (6) Vlasov, AV (2017). The evolution of e-money. European Research Studies Journal, 20(1), 215-224. (7)

Yuswandy Yoedy. (2013). Analysis of the Effect of World Oil Prices, World Gold Prices, Rupiah Exchange Rate Against USD and JCI on Stock Returns. Journal of Capital Markets and Banking, 1, 1-23. (2)

Ghozali, Imam. (2011). Application of Multivariate Analysis With IBM SPSS 19 Program. Fifth Edition. UNDIP research agency, Semarang 